\title{
Soil Resistance to Penetration and Least Limiting Water Range for Soybean Yield in a Haplustox from Brazil
}

\author{
Amauri Nelson Beutler ${ }^{1 *}$, José Frederico Centurion ${ }^{1}$ and Alvaro Pires da Silva ${ }^{2}$ \\ ${ }^{1}$ Universidade Estadual Paulista (UNESP/FCAV); Departamento de Solos e Adubos; Via de Acesso Rod. Paulo \\ Donato Castellane, s/n; 14880-000; amaurib@yahoo.com.br; Jaboticabal - SP - Brasil. ${ }^{2}$ Escola Superior de \\ Agricultura Luiz de Queiroz (ESALQ/USP); Departamento de Ciência do Solo; Piracicaba - SP - Brasil
}

\begin{abstract}
The objective of this study was determine the resistance to penetration (PR), least limiting water range (LLWR) and critical bulk density $\left(D_{b-c r i t}\right)$ for soybean yield in a medium-textured oxisol (Haplustox). The treatments represented the soil compaction by passing a tractor over the site 0,1,2, 4, and 6 times, with 4 replications in a randomized experimental design. Samples were collected from 0.02-0.05, 0.07-0.10 and 0.15-0.18 m depths. Soybean (Glycine max cv. Embrapa 48) was sowed in December 2002. Plant height, number of pods, aerial dry matter, weight of 100 seeds, and the yield in $3.6 \mathrm{~m}^{2}$ plots were recorded. Soybean yield started reduction at the PR of $0.85 \mathrm{MPa}$ and $D_{b}$ of $1.48 \mathrm{Mg} \mathrm{m}^{-3}$. The LLWR was limited in highest part by water content at field capacity (0.01 MPa tension) and in lowest part by water content at $P R_{\text {crit }}$, achieved the $D_{b-c r i t}$ to yield at $1.48 \mathrm{Mg} \mathrm{m}^{-3}$.
\end{abstract}

Key words: Glycine max, water content, resistance to penetration, bulk density

\section{INTRODUCTION}

Soybean production in Brazil has shown an annual increase in the mean yield due to a higher investment in agriculture chemicals. However, little investment has been given to the problems of soil compaction in the production of soybeans. Although difficult to evaluate, soil compaction of anthropic origin is caused by mechanical forces related especially to the traffic of heavy machinery and equipment on moist soils, which can cause significant reduction in the yield and result in increases in production costs (Ralisch and Tavares Filho, 2002). Therefore, it is necessary to know the compaction levels that reduce yield for the appropriate soil management so that preventive and corrective strategies for each soil type and condition can be applied to improve the soil quality and maximize yield.

Soil compaction is a structural alteration that results in a reorganization of its particles and aggregates, as well as a reduction in the total porosity and macroporosity, thus impairing the infiltration and water movement as well as the availability of soil nutrients. Consequently, soil compaction causes a reduction in the penetration and ramification of the roots, therefore, affecting plant development of the aerial segments (Håkansson and Voorhees, 1998; Ralisch and Tavares Filho, 2002; Goedert et al., 2002).

Water infiltration, porosity, bulk density $\left(D_{b}\right)$, and soil resistance to penetration $(P R)$ are some of the physical attributes that are used to characterize soil compaction. Nowadays, $P R$ is considered the most indicative attribute of soil compaction in

\footnotetext{
* Author for correspondence
} 
management systems (Busscher et al., 2000; Beutler et al., 2001). This is because it is directly related to plant growth (Letey, 1985) and shows a strong relationship with plant root growth (Hoad et al., 2001). However, it can have values in the order of 2 to 8 times higher than the maximum axial pressure that roots cause (Misra et al., 1986), and it can be influenced by the moisture, texture, and the soil structural condition (Hamblim, 1985; Tardieu, 1994). All of these factors make it difficult to obtain the critical values of $P R$ for the development of the particular crop. Hence, water content at field capacity is considered appropriate to determine soil resistance to penetration and root growth (Smith et al., 1997), and usually it is used in most of the studies where the $P R$ is determined and related at the critical value of $2.0 \mathrm{MPa}$.

Values of $P R$ that limit root development are in the range between 1.5 to $4.0 \mathrm{MPa}$, with $2.0 \mathrm{MPa}$ the most accepted value (Silva et al., 1994; Tormena et al., 1998; Imhoff et al., 2001). Studies conducted by Goedert et al. (2002) showed that $P R$ of 1.1 MPa did not affect soybean yield in heavy clay Red-Yellow Latosol (Hapludox) and clay Red Latosol. Silva et al. (2000) reported that the yield of soybeans was not affected in clay Red Latosol with $P R$ of $1.5 \mathrm{MPa}$. Moreover, Mielniczuk et al. (1985) did not find alteration in the growth of the aerial dry matter of soybean in Dusky-Red Latosol (Haplustox) when $P R$ was $2.3 \mathrm{MPa}$, in greenhouse. To evaluate soil compaction and soil quality to root development, besides the $P R$, there is also the least limiting water range $(L L W R)$ index. This index was proposed by Letey (1985) and developed by Silva et al. (1994). The first study in Brazil was conducted by Tormena et al. (1998). It define the ideal soil water content range, in which the limitations for root growth were due to the availability of water, air, and $P R$ were minimal.

The index $L L W R$ consists of physical attributes that act directly on plant growth (Letey, 1985). Its highest limit is the soil water content at its field capacity at $0.01 \mathrm{MPa}$ tension (Reichardt, 1988), or the soil water content of the soil with porosity aeration at 10\% (Gupta and Allmaras, 1987). Its lowest limit is the soil water content at the permanent plant wilting point at $1.5 \mathrm{MPa}$ (Savage et al., 1996) or $P R$ of 2.0 MPa (Silva et al., 1994). Silva and Kay (1996) found that the soil water content outside the limits of the $L L W R$ inhibited the growth of maize plants. Unfortunately, there are only few studies on the relationship between $L L W R$ index and crop yield in Brazil, therefore more studies are needed especially in these tropical soils.

The soil water content in $P R$ of $2.0 \mathrm{MPa}$ is a factor that reduces most of the $L L W R$ index in compacted soil (Silva et al., 1994; Tormena et al., 1998; Imhoff et al., 2001). Thus, to improve soil management, the level of $P R$ that limits crop development in tropical soils should be used to increase the accuracy of the $L L W R$ index. An increase in $D_{b}$ reduces the $L L W R$ down to zero (Silva et al., 1994; Imhoff et al., 2000, 2001) at the critical bulk density $\left(D_{b-c r i t}\right)$ value for root growth and when corrective procedures are needed to loosen the soil to avoid loss in yield. However, more studies must be conducted to correlate physical attributes with crop yield and define useful field levels.

The objective of this study was to determine the $P R, L L W R, D_{b \text {-crit }}$ for soybean yield in a Haplustox.

\section{MATERIALS AND METHODS}

The experiment was conducted at the Universidade Estadual Paulista - Faculdade de Ciências Agrárias e Veterinárias experimental farm in Jaboticabal (SP, Brazil), located between the geographic coordinates of Southern latitude $21^{\circ} 15^{\prime} 29^{\prime \prime}$, at the Greenwich West longitude of $48^{\circ} 16^{\prime}$ '53" at an altitudes of $607 \mathrm{~m}$. Local climate is Cwa-type according to Köppen system. Daily pluviometric precipitation during the crop production cycle (December to March) is shown in Figure 1.

The soil was a typical dystrophic Red Latossol, moderate A, kaolinitic hypoferric, medium-texture (Haplustox). Particle size distribution in the soil was determined through dispersion with $\mathrm{NaOH}$ $\left(0.1 \mathrm{~mol} \mathrm{~L}^{-1}\right)$ and slow agitation over $16 \mathrm{~h}$. The clay content was obtained through the pipette method (Gee and Bauder, 1986). Haplustox had $271 \mathrm{~g} \mathrm{~kg}^{-1}$ of clay, $42 \mathrm{~g} \mathrm{~kg}^{-1}$ of silt and $687 \mathrm{~g} \mathrm{~kg}^{-1}$ of sand, in $0.20 \mathrm{~m}$ depth.

Soil tillage at $0.30 \mathrm{~m}$ depth, followed by a harrowing to level the soil, was conducted. Soil compaction was conducted through a side-by-side traffic of an $11 \mathrm{Mg}$ tractor with four tires of the same width $(0.40 \mathrm{~m})$, thus covering all soil surfaces. The treatments were: $0,1,2,4$ and 6 tractors passed one day after raining, in water content at tension of $0.01 \mathrm{MPa}$, in $9.0 \mathrm{~m}^{2}$ plots. The experimental design was completely 
randomized with five treatments and four replications.

Soybean seeds (Glycine max cv. Embrapa 48) were sowed on December 10, 2002 at a $0.05 \mathrm{~m}$ depth in rows $0.45 \mathrm{~m}$ apart, and 20 plants/m (10 days post-sowed). Soil was chemically analyzed based upon Raij et al. (1987), and was supplemented with $0.05 \mathrm{Mg} \mathrm{ha}^{-1}$ of ammonium sulfate, $0.125 \mathrm{Mg} \mathrm{ha}^{-1}$ triple superphosphate and
$0.085 \mathrm{Mg} \mathrm{ha}^{-1}$ potassium chloride for the soybean expected yield of $3.0 \mathrm{Mg} \mathrm{ha}^{-1}$, according to Raij et al. (1996). Weed control was done by hand. Plant height, number of pods and aerial dry matter, weight of 100 seeds and soybean yield per hectare were evaluated for the $3.6 \mathrm{~m}^{2}$ plots.

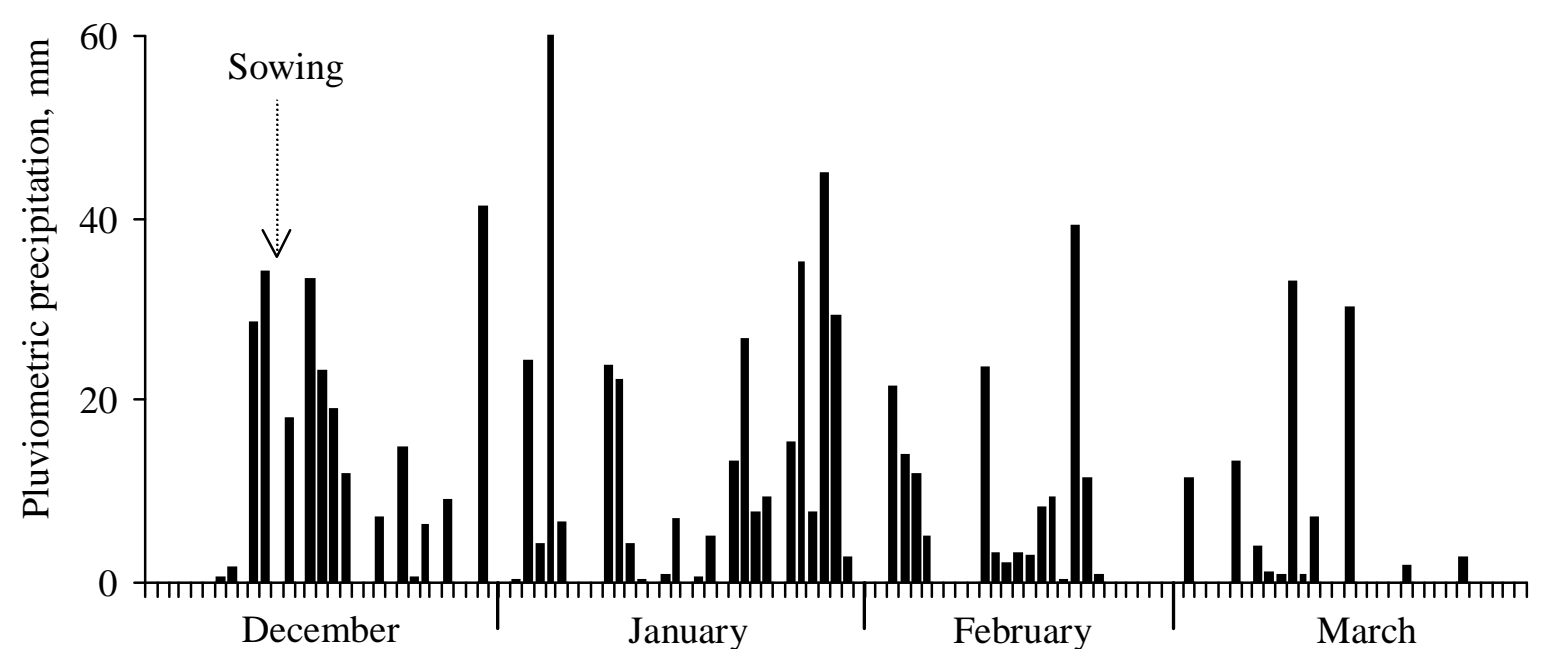

Figure 1 - Daily pluviometric precipitation during the cycle of soybean culture

After the soybean sowing, data on soil samples were collected by a $53.16 \times 10^{-6} \mathrm{~m}^{3}$ cylinders from $0.02-0.05,0.07-0.10$ and $0.15-0.18 \mathrm{~m}$ depth for $P R$ and $D_{b}$ are shown in Table 1. Samples were submitted at $0.01 \mathrm{MPa}$ tension and when they reached stability, the $P R$ was determined utilizing an electronic penetrometer at a constant penetration velocity of $0.01 \mathrm{~m} \mathrm{~min}^{-1}$ with a cone that had an area of $3.14 \times 10^{-6} \mathrm{~m}^{2}$. This penetrometer was equipped with a linear probe and a charge cell of $20 \mathrm{~kg}$ linked to a microcomputer according to Tormena et al. (1998).

Least limiting water range $(L L W R)$ was determined by collecting two replications of six samples from the three depths previously mentioned thus making 36 samples per treatment, which were saturated and submitted at 0.006, 0.01, 0.033 , 0.06, 0.1, and $0.3 \mathrm{MPa}$ tension in a Richard's pressure chamber (Klute, 1986). At stability, samples were weighed and two determinations per sample on the $P R$ at 0.01 to $0.02 \mathrm{~m}$ depth were conducted, compiling 100 evaluations/sample, which were utilized to obtain the mean value for $P R$. These values $\left(\mathrm{kgf} \mathrm{cm}^{-2}\right)$ were multiplied by the factor 0.098 to transform them into MPa.

The water content retained at each tension (Klute, 1986) and $D_{b}$ (Blake and Hartge, 1986) were also determined. The fitness of the soil-water retention curve was according to the model proposed by Genuchten (1980), from which the soil water content at field capacity (0.01 MPa tension) and the permanent wilting point (1.5 $\mathrm{MPa}$ tension) were estimated. The aeration of the soil porosity at $10 \%$ was obtained as $\theta_{\mathrm{AP}}=\theta_{\mathrm{S}}-0.1$, where $\theta_{\mathrm{AP}}$ was the water content where the porosity aeration at $10 \%$ was limiting $\left(\mathrm{m}^{3} \mathrm{~m}^{-3}\right)$ and $\theta_{\mathrm{S}}$ was soil water content at saturation $\left(\mathrm{m}^{3} \mathrm{~m}^{-3}\right)$.

The fitness of the values of $P R$ were based upon the volumetric water content and the $D_{b}$ through the non-linear model proposed by Busscher (1990) defined as $\ln P R=\ln \mathrm{a}+\mathrm{b} \ln \theta+\mathrm{c} \ln D_{b}$, where $P R$ was the soil resistance to penetration $(\mathrm{MPa}) ; \theta$ was the volumetric water content $\left(\mathrm{m}^{3} \mathrm{~m}^{-3}\right) ; D_{b}$ was the bulk density $\left(\mathrm{Mg} \mathrm{m}^{-3}\right)$, and $\mathrm{a}, \mathrm{b}$ and $\mathrm{c}$ were coefficients obtained through the model fitness. 
The $P R$ values utilized in model ranged between $0.05-18.90 \mathrm{MPa}$; $\theta$ from $0.10-0.30 \mathrm{~m}^{3} \mathrm{~m}^{-3}$ and $D_{b}$

from 1.11-1.84 $\mathrm{Mg} \mathrm{m}^{-3}$.

Table 1 - Means $(n=2)$ of soil resistance to penetration and bulk density evaluated from different tractor passed and depth in Haplustox.

\begin{tabular}{|c|c|c|c|c|c|c|c|c|c|c|}
\hline \multirow{3}{*}{$\begin{array}{c}\text { Depth } \\
\text { m }\end{array}$} & \multicolumn{5}{|c|}{ Soil resistance to penetration, $\mathrm{MPa}^{*}$} & \multicolumn{5}{|c|}{ Bulk Density, $\mathrm{Mg} \mathrm{m}^{-3}$} \\
\hline & \multicolumn{5}{|c|}{ Tractor passed } & \multicolumn{5}{|c|}{ Tractor passed } \\
\hline & $\mathbf{0}$ & 1 & 2 & 4 & 6 & $\mathbf{0}$ & 1 & 2 & 4 & 6 \\
\hline $0.02-0.05$ & 0.21 & 1.00 & 1.92 & 3.58 & 4.57 & 1.19 & 1.54 & 1.70 & 1.74 & 1.80 \\
\hline $0.07-0.10$ & 0.32 & 2.38 & 2.63 & 4.40 & 4.10 & 1.31 & 1.68 & 1.76 & 1.82 & 1.81 \\
\hline $0.15-0.18$ & 0.65 & 2.07 & 3.65 & 3.64 & 4.07 & 1.46 & 1.64 & 1.74 & 1.77 & 1.78 \\
\hline Average $(0.0-0.20)$ & 0.39 & 1.82 & 2.40 & 3.87 & 4.25 & 1.32 & 1.62 & 1.73 & 1.78 & 1.80 \\
\hline
\end{tabular}

* Values were recorded in soil with its water content at field capacity (0.01 MPa tension).

The volumetric water content, when the $P R$ at $0.85 \mathrm{MPa}$ was critical, was estimated through the equation $\theta=P R_{\text {-crit }} /\left(\mathrm{e}^{\mathrm{a} *}\left(D_{b}{ }^{\mathrm{c}}\right)\right)^{1 / \mathrm{b}}$, where $\theta$ was the water content an $P R_{\text {-criti }} ; P R_{\text {-crit }}$ was the critical level of $P R$; a was the intercept, $\mathrm{b}$ was the estimated parameter for the water content and c was the coefficient found for $D_{b}$. Values for $L L W R$ were determined for each sample based upon the methodology by Silva et al. (1994). Results were evaluated through analysis of variance. Regression analyses were used between $P R$ and $D_{b}$ with soybean yield.

\section{RESULTS AND DISCUSSION}

Plants heights were reduced starting from $P R$ at 1.46 MPa and the aerial dry matter as well as the number of pods per plant lowered linearly starting from $P R$ at $0.39 \mathrm{MPa}$ (Fig. 2). Mielniczuk et al. (1985) found a lower weight of soybean aerial dry matter starting from $P R$ at $2.35 \mathrm{MPa}$ in a Haplustox under greenhouse conditions. Beutler and Centurion (2003) reported that the soybean aerial dry matter under greenhouse conditions decreased starting from $P R$ at 2.12 and 2.69 MPa in a Haplustox and a Eutrustox, respectively, for the retained water content at $0.01 \mathrm{MPa}$ tension.

Hakansson and Voorhees (1998) and Ralisch and Tavares Filho (2002) reported that smaller development of the aerial plant segments in compacted soils was due to the reduction in the penetration and ramification of roots caused by the mechanical resistance of the soil, and in consequence of the low infiltration and movement of water as well as the availability of nutrients in soil. Moreover, according to Hoad et al. (2001), in compacted soils a reduction in the length and an increase in the thickness of the roots occured, thus decreasing the soil/root contact area and therefore, causing a lower resistance in the roots xylem transport when compared to those of thinner roots. Results on the weight of 100 seeds did not differ significantly between the treatments, although they had a linear decrease as the $P R$ increased (Fig. 2d).

The maximum yield of soybean of $3.01 \mathrm{Mg} \mathrm{ha}^{-1}$ was within the range of the average crop yield and started decreasing at $P R$ of $0.85 \mathrm{MPa}$ and $D_{b}$ of $1.48 \mathrm{Mg} \mathrm{m}^{-3}$ (Fig. 3). Beutler and Centurion (2003) reported that in the same soil type, soybean yield started decreasing at $P R$ of 2.22 and $1.66 \mathrm{MPa}$ for the water content retained at 0.01 and $0.05 \mathrm{MPa}$, respectively, under greenhouse conditions. The smaller $P R$ value for which soybean yields was reduced in the field was probably due to the greater variations in the soil water content during the soybean cycle (Fig. 1), which was known to have a direct relationship with the critical $P R$ value (Dexter, 1987; and Tardieu, 1994). Thus, having the soil water content exponential inverse relation with $P R$, in the days with lesser water content, possibly occur drastically increment on $P R$ to root growth, difficulting its development and water and nutrients absorption. In other side, also it can have occurred deficiency of aeration in the compacted soil, as verified by Ekwue and Stone (1995), mainly when followed days of rain had occurred, that also can have affected the root and plant development with the compaction.

The literature cites values for $P R$ at $2.0 \mathrm{MPa}$ (Silva et al., 1994) and $D_{b}$ at $1.55 \mathrm{Mg} \mathrm{m}^{-3}$ for loamy clay soils (Camargo and Alleoni, 1997) as critical for root system development. Thus, through quadratic 
regressions fitted to $P R$ and $D_{b}$ data (Fig. 3), a small decrease in soybean yield was found at 5.18 and $2.28 \%$, for the critical values of 2.0 $\mathrm{MPa}$ and $1.55 \mathrm{Mg} \mathrm{m}^{-3}$ to $P R$ and $D_{b}$, respectively. However, $P R$ critical values vary according to soil type (Beutler and Centurion, 2003). Silva et al. (1994) reported that the selection of $P R$ critical values modified the sensibility and accuracy of $L L W R$.

Figure 4 showed that when the $D_{b}$ was at 1.13 $\mathrm{Mg} \mathrm{m}^{-3}$ and higher, the $L L W R$ was reduced due to $P R$, i. e., only areas where the soil was loose and not had heavy traffic, the $P R$ was not a limiting factor of $L L W R$. The upper limit was the soil water content at field capacity. Tormena et
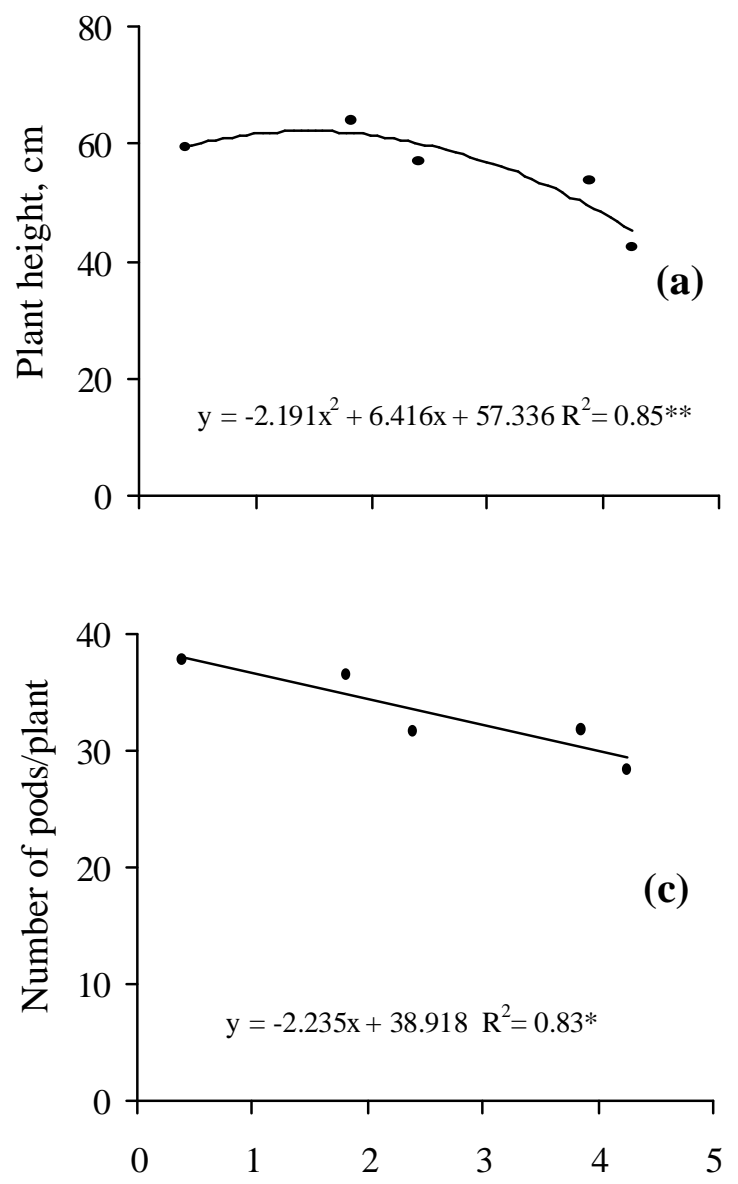

al. (1998) and Imhoff et al. (2001) found that in tropical soils, the $L L W R$ was limited in the upper part due to the water content at field capacity, and in the lower part due to $P R$. Thus, these data illustrated the need to know the limiting levels of $P R$ for different crops and for different types of soils.
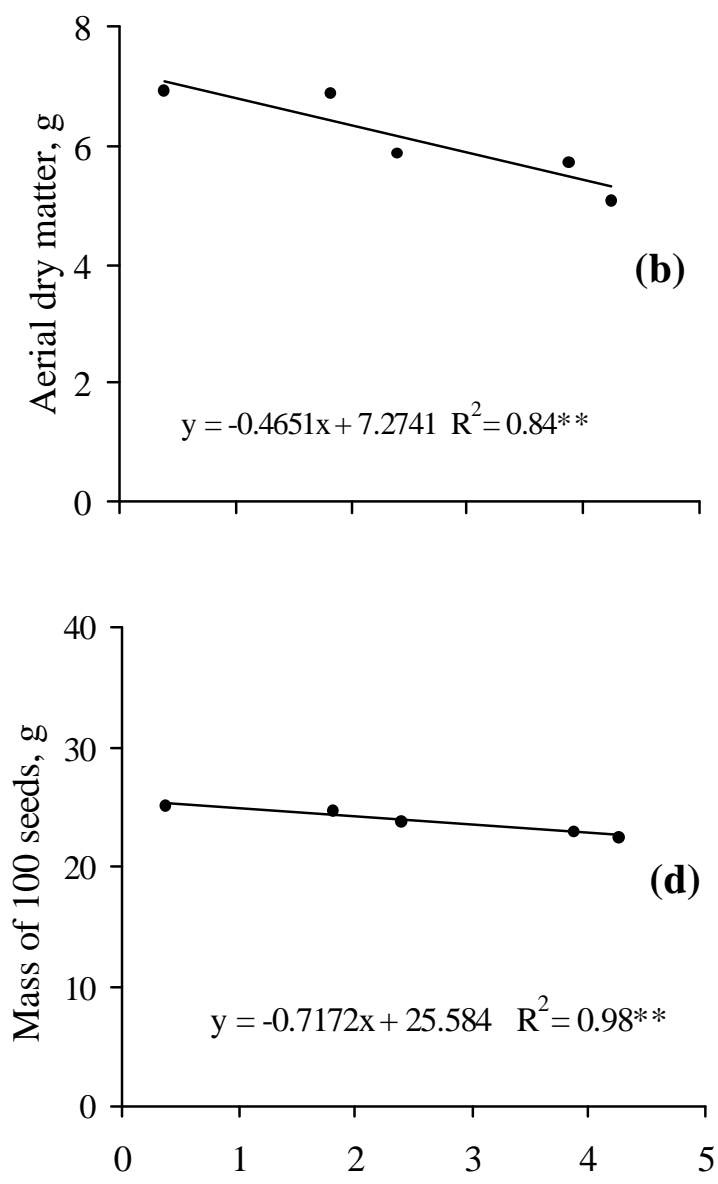

Soil resistance to penetration, $\mathrm{MPa}$

Figure 2 - Regression analysis between $P R$ and plants height (a), aerial dry matter (b), number of pods/plant (c) and weight of 100 seeds $(\mathbf{d})(\mathrm{n}=4)$. **, * Significant at 1 and $5 \%$ of probability, respectively 


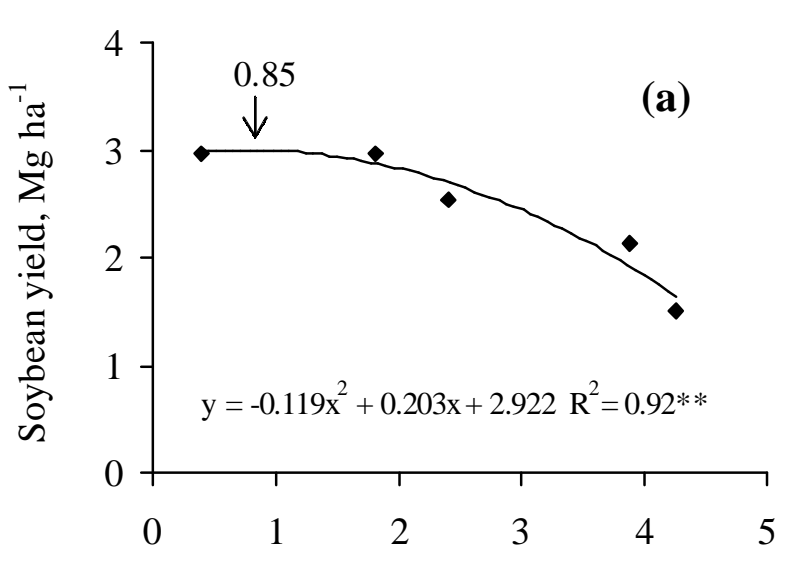

Soil resistance to penetration, MPa

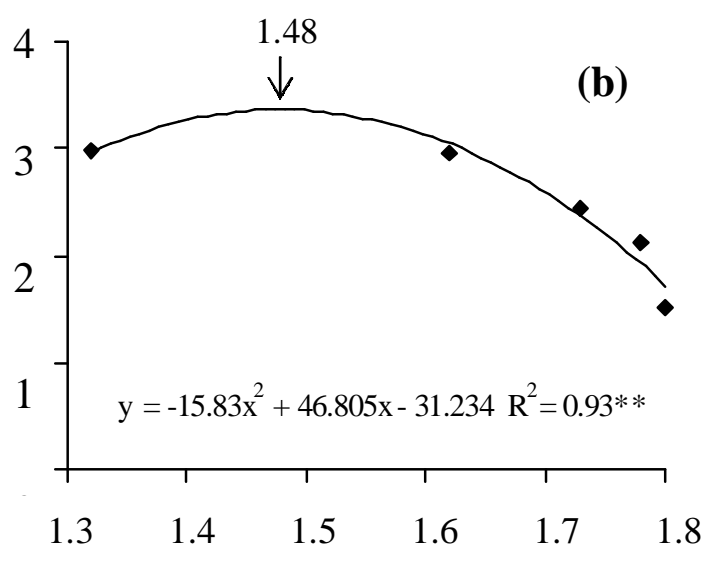

Bulk density, $\mathrm{Mg} \mathrm{m}^{-3}$

Figure 3 - Regression analysis between $P R(\mathbf{a})$ and $D_{b}(\mathbf{b})$ with soybean yield in Haplustox $(\mathrm{n}=4)$. ** Significant at $1 \%$ of probability

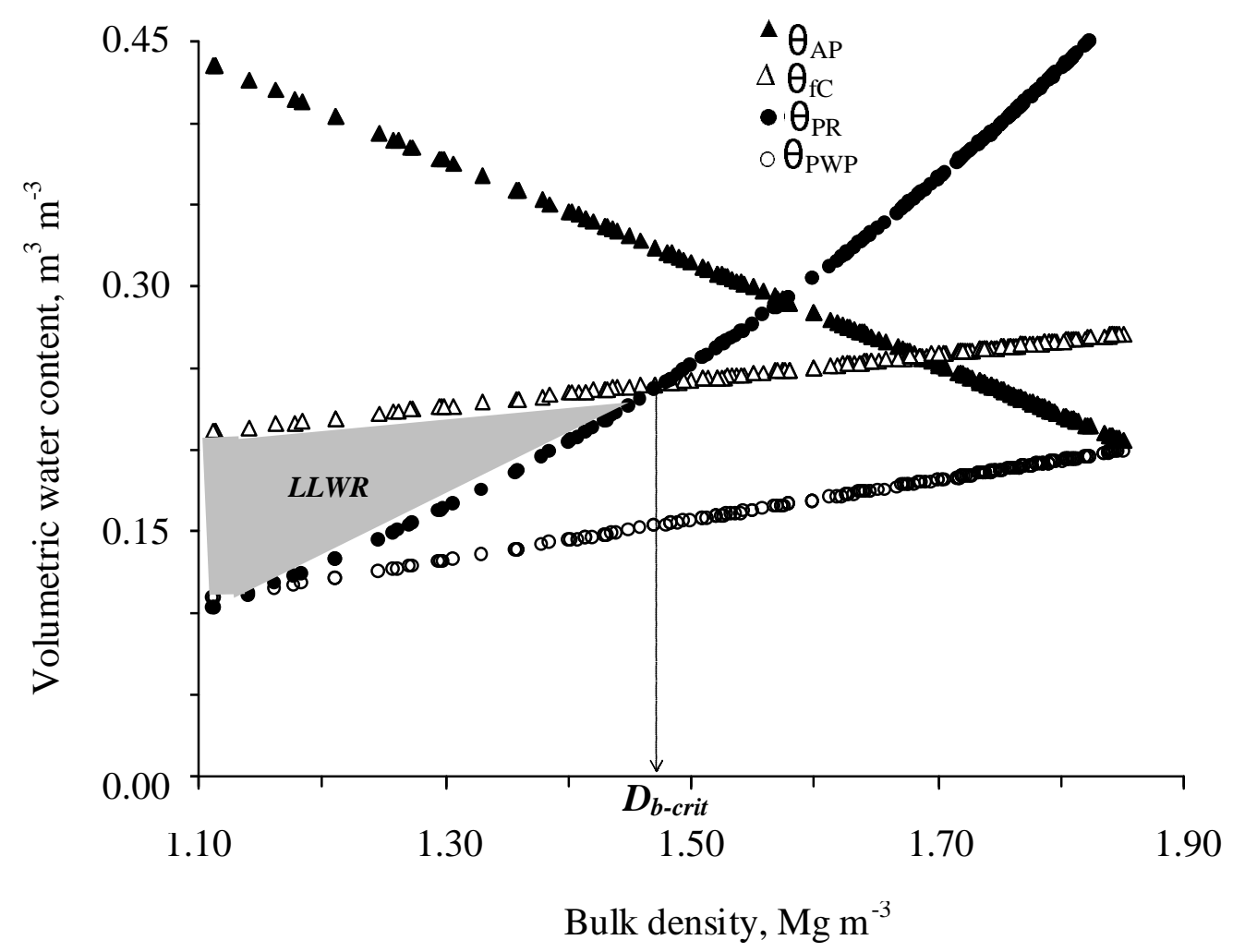

Figure 4 - Variation in the volumetric water content $(\theta)$ with bulk density for the critical limits at aeration porosity $\left(\theta_{\mathrm{AP}}\right)$, field capacity $\left(\theta_{\mathrm{fC}}\right)$, soil resistance to penetration at $0.85 \mathrm{MPa}\left(\theta_{\mathrm{PR}}\right)$, and permanent wilting point $\left(\theta_{\mathrm{PWP}}\right)$ in RLd. $\boldsymbol{L} \boldsymbol{L} \boldsymbol{W R}=$ optimal moisture interval. $\boldsymbol{D}_{\boldsymbol{b} \text {-crit }}=$ Critical bulk density 
Results on $L L W R$ indicated that in tropical soils, this interval was limited by the $P R$ up to the $D_{b \text {-crit }}$, which was $L L W R$ equal to zero. Imhoff et al. (2000) found that the $P R$ curve could be used to guide soil management with the purpose of maintaining the soil quality for plant development. Results on $L L W R$ indicated that in tropical soils, this interval was limited by the $P R$ up to the $D_{b-c r i t}$, which was $L L W R$ equal to zero. Imhoff et al. (2000) found that the $P R$ curve could be used to guide soil management with the purpose of maintaining the soil quality for plant development. Values obtained for $L L W R$ ranged with $D_{b}$, with initial interval of $0.095 \mathrm{~m}^{3} \mathrm{~m}^{-3}$ and decreased with increment of $D_{b}$ at $1.48 \mathrm{Mg} \mathrm{m}^{-3}$, which obtained the $D_{\text {b-crit. }}$ However, Tormena et al. (1998) reported values of $L L W R$ at $0.118 \mathrm{~m}^{3} \mathrm{~m}^{-3}$ in clay Eutrustox. Smaller values of $L L W R$ obtained in medium texture soil in this study contrast Silva et al. (1994), which showed that LLWR was correlated negatively with soil texture. This was due to the oxidic nature of the minerals of a Eutrustox compared to the Haplustox, which caused the formation of a granular structure very strong with greater porous area (Ferreira et al., 1999). The $L L W R$ extent is important because greater it is, lower is the possibility of water deficiency or mechanical restriction to root system, i.e., a lower number of days with soil at lower water content for plant development. Silva et al. (1994) reported that the frequency of soil water content values inside the $L L W R$ depended upon its magnitude and the variability of soil water content based on the climate (i.e., amount of rain). The $D_{b-c r i t}$ of Haplustox obtained in $L L W R$ was $1.48 \mathrm{Mg} \mathrm{m}^{-3}$ (Fig. 4). This was the $D_{b}$ value in which the root system development was limited by the excessive mechanical resistance of the soil if the soil water content corresponded to field capacity. If the water content was lower, the restriction to root system occured by de $P R$ at lower values of $D_{b}$ according to the $L L W R$ model. Therefore, soybean yield should be reduced at lower values or when the $D_{b}$ gets closer to 1.48 $\mathrm{Mg} \mathrm{m}{ }^{-3}$. Figure $3 \mathrm{~b}$ showed that the value of $D_{b}$ which limited the soybean yield was at $1.48 \mathrm{Mg} \mathrm{m}^{-}$ ${ }^{3}$. This illustrated a promising model.

On the other hand, data on the daily precipitation during the soybean cycle (Fig. 1), revealed that from the soybean sowing on December 10, 2002, there were 73 days without dry greater that 4 days until February 22, 2003, followed by 7-dry days and sparse rainfall, which occurred during the filling grain of soybeans. Therefore, during the intensive root development period, the few days without rain demonstrated that the water content to few days was below the field capacity, which was usually reached 2 to 3 days after the rain (Reichardt, 1985). The limiting air porosity was much greater than the field capacity, thus causing little restriction to root development during this period.

In the context, studies conducted by Taylor and Brar (1991) showed the occurrence of changes and reductions in the root length, although it could supply sufficient water and nutrients for the aerial part of the plant, and did not cause lower yield. Beutler and Centurion (2003) found that root development was limited at lower values of $D_{b}$ and $P R$ in relation they aerial dry matter and soybean yield.

The $D_{b}$ value at $1.48 \mathrm{Mg} \mathrm{m}^{-3}$ found in this study as limiting for soybean yield corroborated with the data reported by Camargo and Alleoni (1997), who considered the value of $1.55 \mathrm{Mg} \mathrm{m}^{-3}$ for loamy soils as value which required corrective actions to loosen it up to maintain structural quality and sustainability of grains production. Nevertheless, the values for $P R(0.85 \mathrm{MPa})$ and $D_{b}$ $\left(1.48 \mathrm{Mg} \mathrm{m}^{-3}\right)$ showed a decrease in soybean productivity. For these data to be used as critical values and be adopted as measurements to loosen the soil, an economic analysis of the cost-benefit must be conducted.

With regard to soil management, 1, 2 and 6 passed of an $11 \mathrm{Mg}$ tractor over the same site, when the water content of the soil was close to field capacity (0.01 MPa tension), but caused a decrease of 3.7, 9.4 and $45.6 \%$ in soybean yield (calculate from equation in Figure 3a and Table 1). This showed the importance and necessity of trafficking the soil when it was more dry, thus reducing production costs. Moreover, the critical value for $P R$ of 0.85 and $D_{b}$ of $1.48 \mathrm{Mg} \mathrm{m}^{-3}$ values showing start of decrease in soybean yield in Haplustox, must be analyzed for each soil type, culture, cultivar and management system, in accordance with Arshad et al. (1996). We concluded that $P R$ value from which soybean yield decreased was smaller than the adopted limiting value of $2.0 \mathrm{MPa}$, and that the LLWR was promising indicator of soil physical quality for soybean yield. 


\section{ACKNOWLEDGEMENTS}

The first author thanks the FAPESP and the second and third the CNPq for the fellowships.

\section{RESUMO}

O objetivo deste estudo foi determinar a resistência do solo à penetração $(\mathrm{RP})$, o intervalo hídrico ótimo (IHO) e a densidade do solo crítica $\mathrm{D}_{\text {sc }}$ para produção de soja em Latossolo Vermelho de textura média. Os tratamentos representam a compactação do solo pela passagem do trator 0,1 , 2,4 e 6 vezes sobre a superfície do solo, com quatro repetições, em delineamento experimental inteiramente casualizado. As amostras de solo foram coletadas nas camadas de $0,02-0,05 ; 0,07$ 0,10 e $0,15-0,18 \mathrm{~m}$. A soja (Glycine max), cultivar Embrapa 48, foi semeada em dezembro de 2002. Foram avaliadas a altura das plantas, número de vagens, massa seca da parte aérea, peso de 100 sementes e produtividade em área de $3,6 \mathrm{~m}^{2}$. A produtividade de soja decresceu a partir da RP de $0,85 \mathrm{MPa}$ e densidade do solo de $1,48 \mathrm{Mg} \mathrm{m}^{-3}$. O IHO foi limitado na parte superior pelo conteúdo de água na capacidade de campo $(0,01 \mathrm{MPa})$ e na parte inferior pela $\mathrm{RP}$, sendo a $\mathrm{D}_{\mathrm{sc}}$ à produção de soja de $1,48 \mathrm{Mg} \mathrm{m}^{-3}$.

\section{REFERENCES}

Arshad, M. A.; Lowery, B. and Grossman, B. (1996), Physical tests for monitoring soil quality. In: Doran, J. W. and Jones, A. J. Methods for assessing soil quality. Madison: Soil Science Society of America. pp. 123-141. (SSSA Special publication; 49).

Beutler, A. N. and Centurion, J. F. (2003), Efeito do conteúdo de água e da compactação do solo na produção de soja. Pesq. Agropec. Bras., 38, 849-856.

Beutler, A. N.; Silva, M. L. N.; Curi, N.; Ferreira, M. M.; Cruz, J. C. and Pereira Filho, I. A. (2001), Resistência à penetração e permeabilidade de Latossolo Vermelho distrófico típico sob sistemas de manejo na região dos cerrados. R.. Bras. Ci. Solo, 25, 167-77.

Blake, G. R. and Hartge, K. H. (1986), Bulk density. In: Klute, A. (Ed.). Methods of soil analysis: physical and mineralogical methods. 2. ed. Madison: American Society of Agronomy. pp. 363-375.

Busscher, W. J. (1990), Adjustment of flat-tipped penetrometer resistance data to a common water content. Am. Soc. Agric. Eng., 3, 519-524.
Busscher, W. J.; Frederick, J. R. and Bauer, P. J. (2000), Timing effects of deep tillage on penetration resistance and wheat and soybean yield. Soil Sci. Soc. Am. J., 64, 999-1003.

Camargo, O. A. and Alleoni, L. R. F. (1997), Compactação do solo $e$ o desenvolvimento das plantas. Piracicaba: Escola Superior de Agricultura Luiz de Queiroz. 132 pp.

Dexter, A. R. (1987), Mechanics of root growth. Plant Soil, 98, 303-312.

Ekwue, E. I. and Stone, R. J. (1995), Irrigation scheduling for sweet maize relative to soil compaction conditions. J. Agric. Engng. Res., 62, 85-94.

Ferreira, M. M.; Fernandes, B. and Curi, N. (1999), Mineralogia da fração argila e estrutura de Latossolos da região sudeste do Brasil. R. Bras. Ci. Solo, 23, 507-514.

Flowers, M. D. and Lal, R. (1998), Axle load and tillage effects on soil physical properties and soybean grain yield on a mollic ochraqualf in northwest Ohio. Soil Till. Res., 48, 21-35.

Gee, G. W. and Bauder, J. W. (1986), Particle-size analysis. In: Klute, A. (Ed.). Methods of soil analysis. 2. ed. Madison: American Society of Agronomy. Part. 1. pp. 383-411.

Genuchten, M. T. A. (1980), A closed-form equation for predicting the hydraulic conductivity of unsaturated soils. Soil Sci. Soc. Am. J., 44, 892-897.

Goedert, W.; Schermack, M. J. and Freitas, F. C. (2002), Estado de compactação do solo em áreas cultivadas no sistema de plantio direto. Pesq. Agropec. Bras., 37, 223-227.

Gupta, S. C. and Allmaras, R. R. (1987), Models to assess the susceptibility of soils to excessive compaction. Adv. Soil Sci., 6, 65-100.

Hakansson, I. and Voorhees, W. B. (1998), Soil compaction. In: Lal, R.; Blum, W. H.; Valentine, C. and Steward, B. A. (Eds.). Methods for assessment of soil degradation Advances in soil science. Boca Raton: CRS Press. pp. 167-179.

Hamblim, A. P. (1985), The influence of soil structure on water movement, crop root growth and water uptake. Adv. Agron., 38, 95-158.

Hoad, S. P.; Russel, G.; Lucas, M. E. and Bingham, I. J. (2001), The management of wheat, barley, and oat root systems. Adv. Agron., 74, 195-254.

Imhoff, S.; Silva, A. P. and Tormena, C. A. (2000), Aplicações da curva de resistência no controle da qualidade física de um solo sob pastagem. Pesq. Agropec. Bras., 35, 1493-1500.

Imhoff, S.; Silva, A. P.; Dias Junior, M. S. and Tormena, C. A. (2001), Quantificação de pressões críticas para o crescimento das plantas. R. Bras. Ci. Solo, 25, 11-18. 
Klute, A. (1986), Water retention: laboratory methods. In: Klute, A. (Ed.). Methods of soil analysis: physical and mineralogical methods. 2. ed. Madison: American Society of Agronomy. pp. 635-660.

Letey, J. (1985), Relationship between soil physical properties and crop production. Adv. Soil Sci., 1, 277-294.

Mielniczuk, J.; Carpenedo, V. and Pedo, F. (1985), Desenvolvimento de raízes em solos compactados. Lav. Arrozeira, 38, 42-43.

Misra, R. K.; Dexter, A. R. and Alston, A. M. (1986), Penetration of soil aggregates of finite size. II. Plant roots. Plant Soil, 94, 59-85.

Raij, B. Van; Cantarella, H.; Quaggio, J. H. and Furlani, A. M. C. (1996), Recomendação de adubação e calagem para o estado de São Paulo. 2. ed. Campinas: Instituto Agronômico. 285 pp. (Boletim Técnico; 100).

Raij, B. Van; Quaggio, J. A.; Cantarella, H.; Ferreira, M. E.; Lopes, A. S. and Bataglia, O. C. (1987), Análise química do solo para fins de fertilidade. Campinas: Fundação Cargill. 170 pp.

Ralisch, R. and Tavares Filho, J. (2002), Compactação: uma preocupação pertinente. A Granja, 646, 55-57.

Reichardt, K. (1988), Capacidade de campo. R. Bras. Ci. Solo, 12, 211-216.

Reichardt, K. (1985), Processos de transferência no sistema solo - planta - atmosfera. Piracicaba, Fundação Cargill. 445 pp.

Savage, M. J.; Ritchie, J. T.; Land, W. L. and Dugas, W. A. (1996), Lower limit of soil water available. Agron. J., 88, 651-844.

Silva, A. P. and Kay, B. D. (1996), The sensitivity of shoot growth of corn to the least limiting water range of soils. Plant Soil, 184, 323-329.

Silva, A. P.; Kay, B. D. and Perfect, E. (1994), Characterization of the least limiting water range. Soil Sci. Soc. Am. J., 58, 1775-1781.
Silva, V. R.; Reinert, D. J. and Reichert, J. M. (2000), Resistência mecânica do solo à penetração influenciada pelo tráfego de uma colhedora em dois sistemas de manejo do solo. Ci. Rural, 30, 795-801.

Smith, C. W.; Johnston, M. A. and Lorentz, S. (1997), The effect of soil compaction and soil physical properties on the mechanical resistance of South African forestry soils. Geoderma, 78, 93-111.

Tardieu, F. (1994), Growth and functioning of roots and to root systems subjected to soil compaction. Towards a system with multiple signaling. Soil Till. Res., 30, 217-243.

Taylor, H. M. and Brar, G. S. (1991), Effect of soil compaction on root development. Soil Till. Res., 19, 111-119.

Tormena, C. A.; Silva, A. P. and Libardi, P. L. (1998), Caracterização do intervalo hídrico ótimo de um Latossolo Roxo sob plantio direto. R. Bras. Ci. Solo, 22, 573-581.
Received: May 14, 2004; Revised: October 29, 2004; Accepted: May 20, 2005. 